The Faculty Advisor Perspective

\title{
Deepening Scholarship through Study Abroad
}

The intersection between undergraduate education, scholarship, and study abroad is wonderfully illustrated in the circumstances of Amy Walter's senior thesis project at Claremont McKenna College. I came to know Amy through three different seminars analyzing various aspects of Latin America and Mexican politics. Thus, it was not surprising when she chose to study in Chile immediately prior to her senior year. As her professor, I too had shared a prior interest in Chile. Along with an international team of distinguished scholars, I directed a large-scale survey research project funded by the Hewlett Foundation in California, which explored citizen views of democracy in three Latin American countries, Costa Rica, Chile and Mexico. We chose Chile because it had undergone such severe political oppression in the 1970s and 1980s, yet had made a remarkable transition to democracy in the last decade. Amy became familiar with the published and raw data from this study in a seminar.

Stimulated by her classroom experiences, she decided to explore the impact of media on the political values and attitudes of ordinary Chileans. As she reports in the introduction to her own essay, she traveled to Chile to study at Chilean universities, taking advantage of that resource to come in contact with several prominent figures in the journalism world. She was able to establish a more realistic context for the setting of her research, which explored the period under the infamous military dictatorship of General Pinochet, as well as the following years of democratic transformation. The process of talking to actual actors who participated in the events she describes in her research gave her knowledge that is difficult to capture otherwise.

The availability of information to scholars in countries like Chile is often difficult to obtain, especially from the outside. By being in the right place at the right time, Amy experienced one of those rare fortuitous circumstances where she discovered a wealth of relevant material, in no less an unexpected place than the curbside of her next door neighbor, an individual who had collected hundreds of newspaper clippings from the historic period she hoped to study. As Amy reports, keeping such material in your home during the Chilean military dictatorship could easily have resulted in lifethreatening consequences. 
One of the special benefits of living abroad is that it allows you to raise your scholarly work from a merely intellectual plane to that of real life. Amy was able to see from her classes, from living in Santiago, and from her conversations with numerous Chileans how the media performed a crucial role in reinforcing a societal ambience conducive to participatory democracy in Chile. Thus, she was able to understand the meaning of this on a personal as distinct from an intellectual level.

Another consequence of studying in another country is that it allows one to compare the cultural experiences of that country to one's own experiences. It is natural to think that journalism is an international profession, but journalism in a Latin American context has a long tradition different from that found in the United States. Living in another cultural setting allows a person to see how such a profession has evolved and why its institutional rules and behavior might be quite different from that found in the United States. It also allows a scholar to understand why the theoretical literature on media influences might not pertain to the Chilean case as readily as it would to other societal settings.

From my own personal and professional experiences I can relive Amy's experiences too. Like Amy, I became interested in Latin America by my freshman year. In those days (the 1960s), formal study abroad programs were rare. Therefore, I made arrangements on my own to study in Mexico. I rode a bus from Santa Ana, California to Mexico City. In crossing the border at Nogales, I encountered my first cultural challenge dealing with Mexican customs. After a two-day trip to the capital, I arrived at the home of Señorita Alducin, the elderly sister of the founder of one of Mexico's leading newspapers, Excelsior. She introduced me to one of her friends, a lively woman who experienced the Mexican Revolution of 1910 personally and regaled me with her stories. I too attended classes at a local university. Like Amy, I came away with a committed interest in Mexico and Latin America, and also like her, a desire to continue my education in that field. Unlike Amy, however, I had no prior scholarly preparation for my experience, thus I missed out, in many cases, on the relevance of what I was learning from those everyday experiences.

Today, no undergraduate student in the United States, when given the opportunity to study abroad, should pass it up. For better or worse, we live in a global world, a dynamic universe in which we must communicate, trade, share resources, and understand each other's values. There is no guarantee English will remain the language of international economics and politics. Given these changes, theory building in the social sciences will increasingly 
emerge from Third-World, not First-World experiences. Only those citizens who know other languages, understand other cultures, and are comfortable in other societal settings are likely to thrive professionally. Thus today, studying abroad is an essential ingredient in the traditional liberal arts education, and is integral to completing a college degree. It, alone, may be the most formative experience of an American college education.

\section{Rod e ric A i C a m p}

Philip M. McKenna Professor of the Pacific Rim

Claremont McKenna College 